\title{
Research on Deformation Mechanisms of a High Geostress Soft Rock Roadway and Double-Shell Grouting Technology
}

\author{
Fengnian Wang $\mathbb{D}^{1,2}$ Shizhuang Chen, ${ }^{3}$ Pan Gao, ${ }^{1,2}$ Zhibiao Guo, ${ }^{1,2}$ and Zhigang Tao $\mathbb{D}^{1,2}$ \\ ${ }^{1}$ State Key Laboratory for Geomechanics and Deep Underground Engineering, China University of Mining and Technology (Beijing), \\ Beijing 100083, China \\ ${ }^{2}$ School of Mechanics and Civil Engineering, China University of Mining and Technology (Beijing), Beijing 100083, China \\ ${ }^{3}$ Research Institute of Geotechnical Engineering, Hohai University, Nanjing 210098, China
}

Correspondence should be addressed to Zhigang Tao; taozhigang@263.net

Received 3 September 2021; Revised 29 September 2021; Accepted 6 October 2021; Published 31 October 2021

Academic Editor: Yu Wang

Copyright (c) 2021 Fengnian Wang et al. This is an open access article distributed under the Creative Commons Attribution License, which permits unrestricted use, distribution, and reproduction in any medium, provided the original work is properly cited.

\begin{abstract}
In this study, the deformation characteristics and mechanical properties of coal and rock mass in the S2N5 working face of the Xiaokang coal mine are analyzed to address the problem of large deformation of soft rocks with high in situ stress surrounding roadways. Through a newly developed grouting pipe, a double-shell grouting technology, consisting of low-pressure grouting and high-pressure split grouting, is proposed for the Xiaokang coal mine. In addition, the effect of grouting is evaluated by borehole peeping and deformation monitoring. The results show that the double-shell grouting technology can effectively improve the overall mechanical properties of the surrounding coal and rock mass, preventing the large deformation and failure of the roadway. This technology can be useful when analyzing and preventing large deformation of soft rock roadways.
\end{abstract}

\section{Introduction}

Controlling the soft rock strata surrounding roadways is important when conducting mining activities $[1,2]$. To control the large deformation of soft rock roadways, it has become necessary to support them with bolt/cable + steel mesh + shotcrete technology [3,4]. However, bolts and anchor cables could not play a full role because of insufficient anchoring force in soft rock, and grouting reinforcement is an effective method to control the deformation of roadway surrounding rock $[5,6]$. Grouting reinforcement technology is an indispensable part of the support design for tunnels with high ground stress and complex geological conditions [7]. Grouting reinforcement technology can effectively improve the mechanical properties and integrity of broken surrounding rock. At the same time, grouting reinforcement can prevent the surrounding rock from becoming unstable and also prevent its damage and failure during mining [8]. There have been many studies on the mechanism and control of large deformation of roadways in soft rock with high in situ stress.

Li. et al. analyzed the failure mechanism of a large span intersection through numerical simulation and proposed a double-bolt control technology to effectively control the deformation of the surrounding rock in roadways [9]. Li. et al. proposed a coupling support technology consisting of a high-toughness sealing layer + hollow grouting cables + full-length anchoring bolts in deep boreholes to effectively control the large deformation of roadways [10]. Fangtian et al. implemented a whole section anchor-grouting reinforcement technology in a coal mine based on a doubleshell anchor-grouting reinforcement mechanism to control the deformation of the rock surrounding a roadway [11]. Wang et al. put forward the concept of "high strength, integrity, and decompression" based on the large deformation mechanism of soft rock surrounding a roadway and developed a confined concrete (CC) support system, which was verified by field tests [12]. Chen et al. proposed a whole 


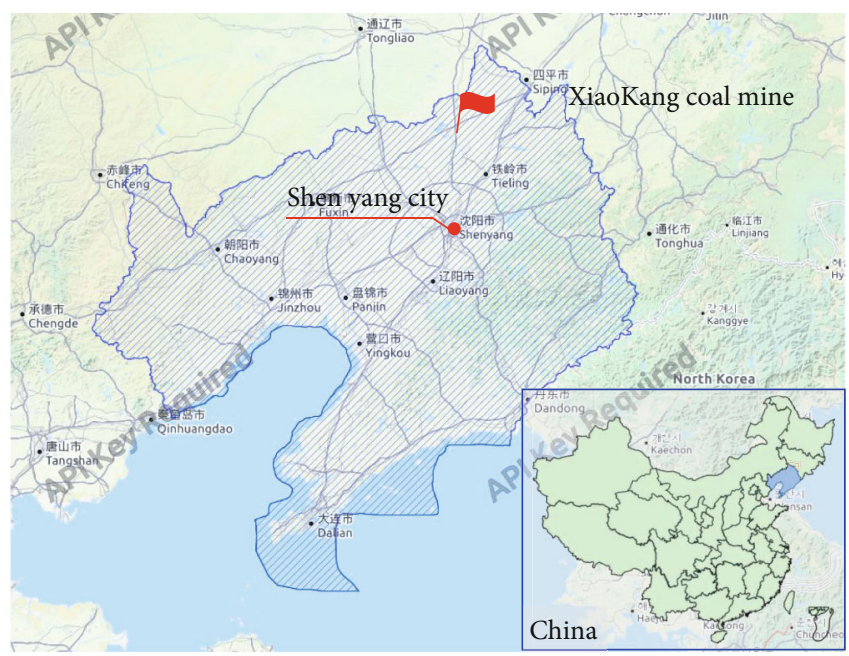

(a)

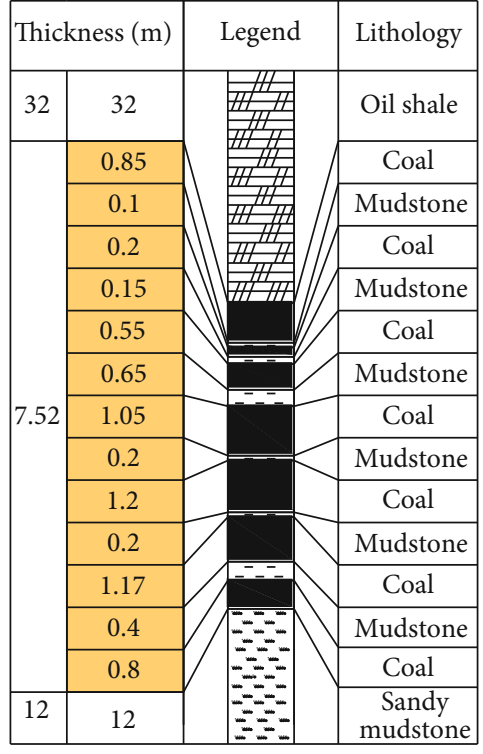

(b)

Figure 1: General situation of the Xiaokang coal mine. (a) Geographical location of the Xiaokang coal mine. (b) Coal seam of S2N5.

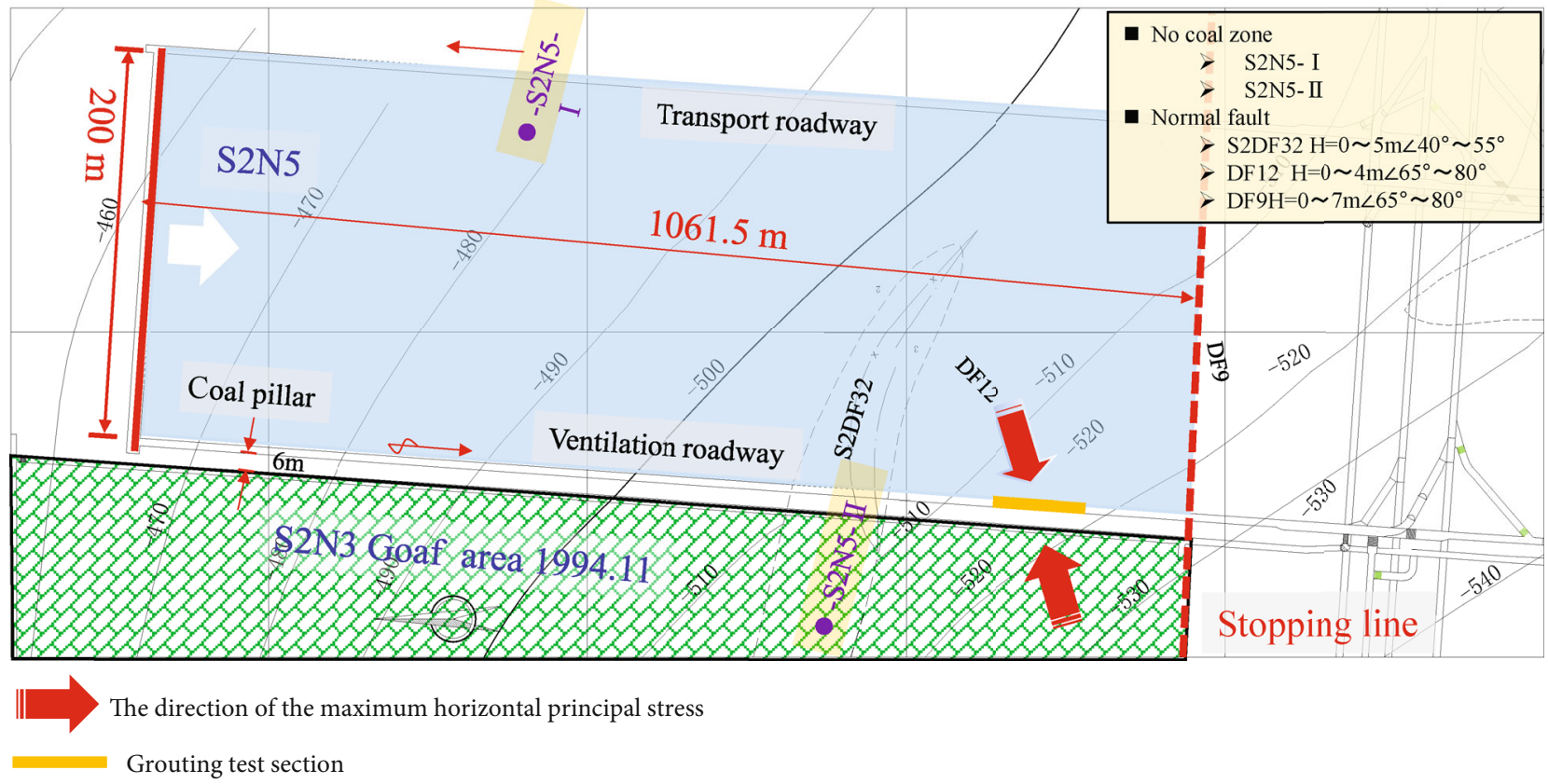

FIGURE 2: Basic situation of the S2N5 working face.

section double arch synergy reinforcement technology of "sprayed concrete + grouting + anchor bolt + anchor cable" to control the deformation of inclined shaft in soft surrounding rock [13]. Zhang et al. proposed a grouting material with low cost and high density for the reinforcement of large-scale floor cracks; the optimal proportion of constituents for the new grouting material (including 1\% foaming agent) was $40 \%$ of cement, $30 \%$ of clay, and $30 \%$ of fly ash [14]. Yang et al. put forward a new grouting method based on the CFD-DEM coupling principle; one typical subgrade section in the Shanghai-Nanjing intercity railway was used to simulate the grouting process and the diffusion mechanism of the slurry at the microlevel [15].

This study mainly analyzes the mechanism of large deformation occurring in roadways surrounded by soft rock with high geostress and the reinforcement of soft broken coal rock mass using inorganic grouting material. Modified coal and rock mass can be effectively reinforced in a roadway surrounded by rock using double-shell grouting technology (low-pressure grouting in shallow surrounding rock and high-pressure split grouting technology in deep surrounding rock) to enhance the strength and the deformation resistance 
TABLE 1: Development of the support system in the Xiaokang coal mine.

Supporting design
Section
Steel arch
Bolts and anchor cables

of the surrounding rock under mining activity. The field application of double-shell grouting technology is achieved using a newly developed grouting conduit and good results are obtained.

\section{Field Overview}

2.1. Engineering Background. The Xiaokang coal mine is located in Kangping County, Shenyang City, Liaoning Province, China, as shown in Figure 1(a). It is $40 \mathrm{~km}$ away from Shenyang City. The mine area is $28.99 \mathrm{~m}^{2}$, and the output is $270 \mathrm{Wt} / \mathrm{a}$. There are no hydrological characteristics of large rivers in the mine area. The structure of the Xiaokang coal mine is influenced by the second subsidence zone of the Neocathaysian system and the Yinshan zonal structural zone of the Tianshan Mountains, where tension-torsion normal faults are welldeveloped. The sliding structure of the mine has multilevel sliding surfaces and small faults in the oil shale on the roof of the coal seam. In addition, the widespread development of gravity sliding structures in the Xiaokang coal mine has destroyed the integrity of the coal roof and increased the mine pressure.

The maximum buried depth of the coal seam in the S2N5 working face is $585 \mathrm{~m}$, and the coal seam inclination is generally $3^{\circ} \sim 6^{\circ}$. The length of the mining area is $1061.5 \mathrm{~m}$, and the width is $200 \mathrm{~m}$ as shown in Figure 2. The average thickness of the coal seam is about $7.52 \mathrm{~m}$ as shown in Figure 1(b). The adjacent working face S2N3 was mined in 1994 with a small pillar $6 \mathrm{~m}$ away from the S2N5 area as shown in Figure 2. Affected by the S2DF32H fault, the roadway deformation in the working face is obvious and the stability of the roadway is difficult to control. Therefore, near the DF12 fault, grouting reinforcement is proposed to control the deformation of S2N5's ventilation roadway.

2.2. Original Support Design of the S2N5 Tunnel. The problem of implementing an adequate support system has been restricting the development of the Xiaokang coal mine [16]. A series of reforms have been carried out on the selection of an appropriate roadway support section, the supporting material of the arch frame, and the anchor cable as shown in Table 1.

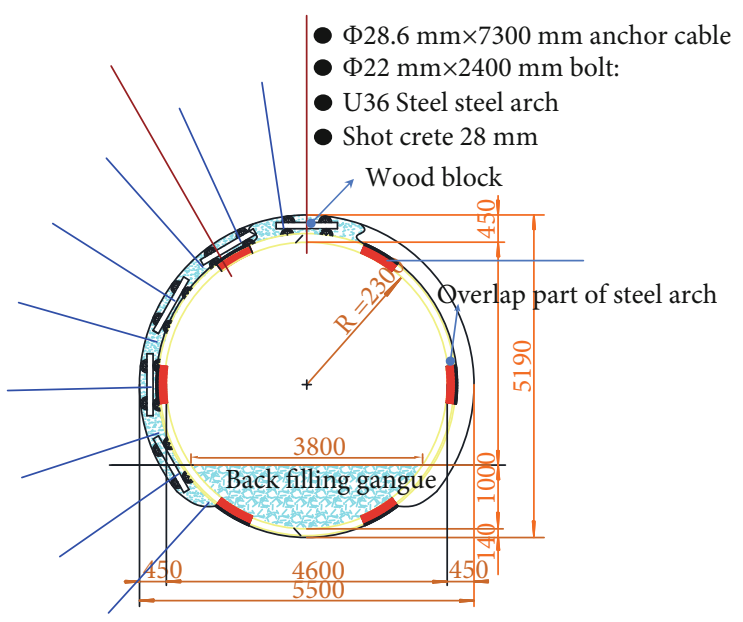

FIgURE 3: Support design of the ventilation roadway of S2N5.

It can be seen from Table 1 that the supporting methods selected for the Xiaokang coal mine have become increasingly more complex and that the support strength has gotten increasingly higher. At present, the roadway in the Xiaokang coal mine has adopted a compound lining structure. The initial support consists of bolts $(2.4 \mathrm{~m})$ and anchor cables $(7.3 \mathrm{~m})$. The row spacing between bolts is $800 \mathrm{~mm} \times 600 \mathrm{~mm}$ and anchor cables is $1600 \mathrm{~mm} \times 1200 \mathrm{~mm}$. The diameter of mining roadway in the S2N5 working face is $4.6 \mathrm{~m}$. Comprehensive mechanized caving mining technology is adopted with a mining height of $3.8 \mathrm{~m}$, and the height of caving mining is $3.72 \mathrm{~m}$. The secondary lining is composed of steel arch (U36) and shotcrete $(28 \mathrm{~mm})$ as shown in Figure 3 . However, the mining roadway, which has had a long service period and a complex engineering-geological environment, still needs to be improved to achieve normal production of the mine.

\section{Failure Characteristics and Mechanism of the Surrounding Rock}

3.1. Failure Characteristics of the Surrounding Rock. Observations of the deformation of the rock surrounding the roadway at the S2N5 working face show that the influence range 


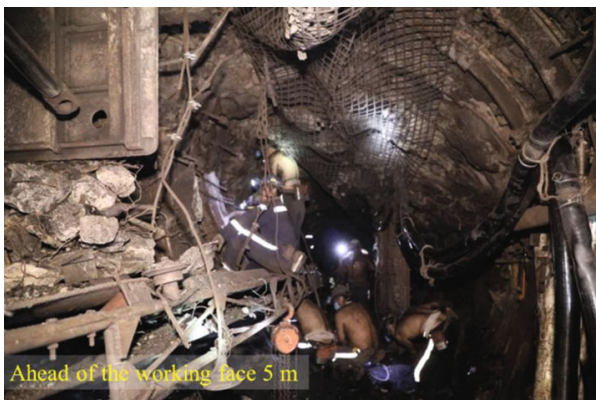

(a)

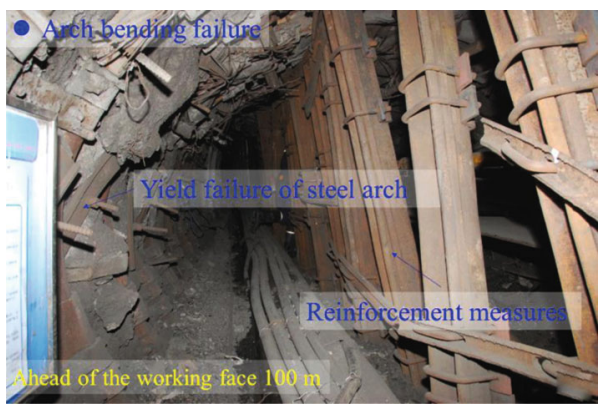

(c)

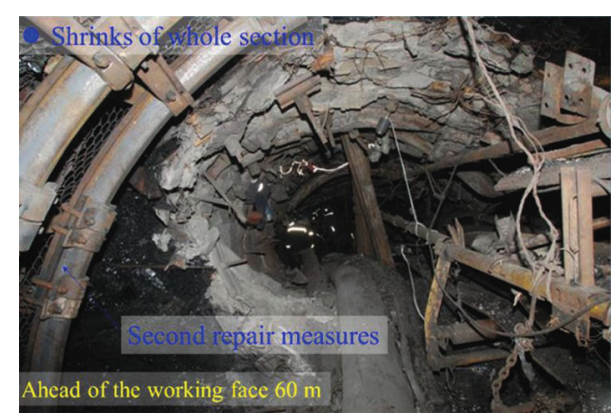

(b)

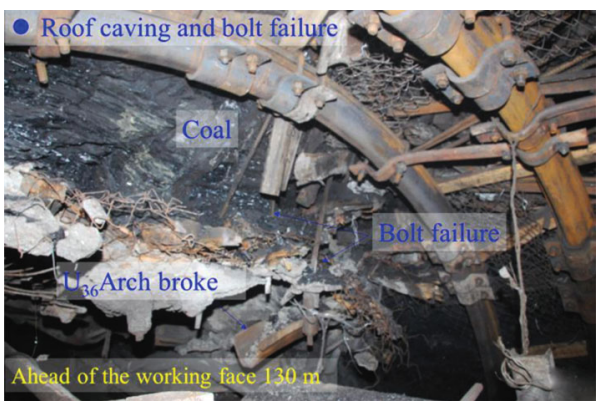

(d)

FIgURE 4: Failure phenomenon of the S2N5 working face.

of the advance working face is up to $200 \mathrm{~m}$. The zoning statistics of the influence area of the working face are as follows.

(1) Abutment pressure affects damage zone I (0-20 m). The roadway is seriously affected by the mining pressure of the working face. Under mining pressure, the roadway section shrinks overall, and the bottom heave phenomenon is particularly obvious. The arch frame of the roadway needed to be dismantled and repaired twice to achieve normal production as shown in Figure 4(a)

(2) Abutment pressure affects damage zone II (20-75 m). The roadway shows the rheological properties of soft rock, and the support structure shrinks overall. The plastic zone is far beyond the control depth of the support structure as shown in Figure 4(b).

(3) Abutment pressure affects damage zone III (75-120 m). The pressure around the roadway causes the support structure to shrink overall under pressure. Because the support structure does not have certain pressure relief characteristics, the U36 arch frame presents different shapes of yielding states, such as folding, bending, and falling off

(4) Abutment pressure affects the IV area $(120-200 \mathrm{~m})$. As the strength of surrounding rock is not coupled with the strength of support body, the failure of roadway starts from a certain point, which is mainly manifested in the form of falling blocks of shotcrete, bending deformation of the steel arch, and the failure of the anchors in the shallow surrounding rock

\subsection{Failure Mechanism of the Surrounding Rock in S2N5}

3.2.1. Low Strength of the Surrounding Rock. The roof of the roadway in the S2N5 working face is mainly composed of coal and shale, and the floor is composed of sandy mudstone. In the laboratory, the strengths of the roof, floor, and coal were tested using the rock strength test system shown in Figure 5. The strength parameters are shown in Table 2. The strengths of the coal, shale, and sandy mudstone are 14.20 MPa, 19.70 MPa, and 17.71 MPa, respectively. The surrounding rock belongs to the typical three-soft coal seam, which has low compressive strength, poor stability, and poor load-bearing capacity [17-20]. In the process of coal mining, areas of stress expansion and collapse of the surrounding rock easily occur due to the concentrated stress in the surrounding rock. The low strength of the rock mass surrounding the roadway is the main cause of the large deformation of the roadway.

3.2.2. Clay Minerals and Microstructure. The rock mineral content and the clay mineral relative content were tested using an X-ray diffractometer, and the results are shown in Tables 3 and 4:

It can be seen from Table 3 that the clay content of the bottom sandy mudstone is $45.7 \%$, and the illite-smectite layer-mixed clay mineral is the main component with a content of $58 \%$, followed by kaolinite (19\%) and illite (15\%). The shale clay composition of the roof is $39.5 \%$, and the main constituents of the clay are the illite-smectite layermixed content (58\%) followed by kaolinite (30\%) and illite (12\%). Both the imonite mixed layer and the kaolinite show strong hydrophilicity and easily soften and disintegrate in contact with water. After the excavation of the working face, 


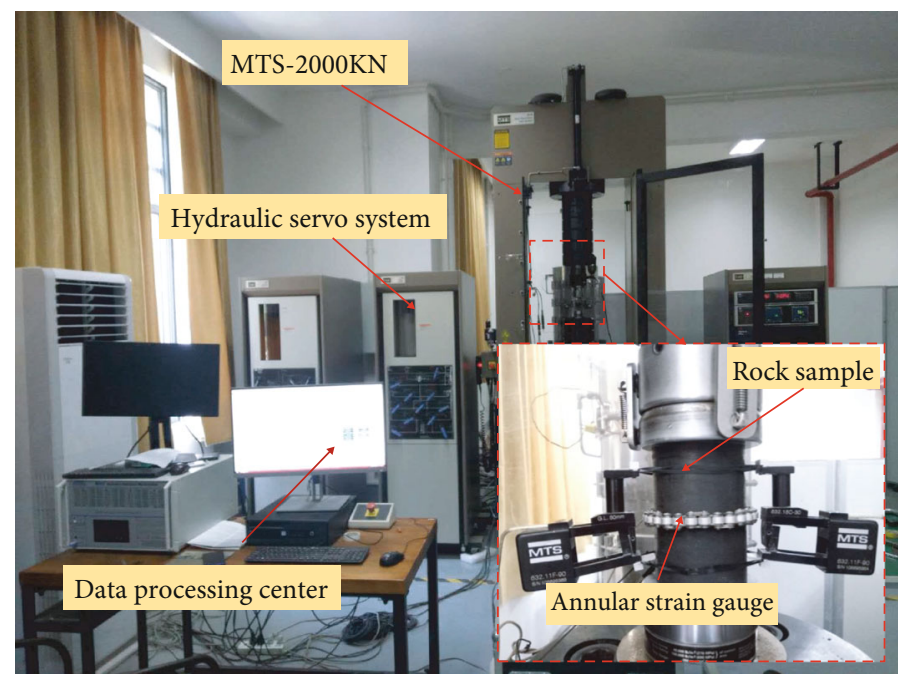

FIGURE 5: Rock strength testing system.

TABle 2: Physical and mechanical parameters of the surrounding rock.

\begin{tabular}{lccccccc}
\hline No. Lithology & $\begin{array}{c}\text { Tensile strength } \\
(\mathrm{MPa})\end{array}$ & $\begin{array}{c}\text { Friction angle } \\
\left({ }^{\circ}\right)\end{array}$ & $\begin{array}{c}\text { Poisson's } \\
\text { ratio }\end{array}$ & $\begin{array}{c}\text { Cohesion } \\
(\mathrm{MPa})\end{array}$ & $\begin{array}{c}\text { Compressive strength } \\
(\mathrm{MPa})\end{array}$ & $\begin{array}{c}\text { Elastic modulus } \\
(\mathrm{GPa})\end{array}$ \\
\hline 1 & Coal & 0.64 & 47.20 & 0.11 & 2.35 & 14.20 & $5.8 \times 103$ \\
2 & Shale & 0.79 & 33.60 & 0.12 & 4.28 & 19.70 & $6.3 \times 10^{3}$ \\
3 & Mudstone & 1.32 & 47.70 & 0.18 & 1.52 & 17.71 & $8.8 \times 10^{3}$ \\
\hline
\end{tabular}

TABLE 3: Mineral content of the surrounding rock.

\begin{tabular}{|c|c|c|c|c|c|c|c|c|c|}
\hline \multirow{2}{*}{ Lithology } & \multicolumn{9}{|c|}{ Mineral content (\%) } \\
\hline & Quartz & Feldspar & Anorthose & Calcite & Dolomite & Siderite & Pyrite & Kaolinite & Clay mineral \\
\hline Mudstone & 47.5 & 1.8 & 5.0 & 1 & 1 & 1 & 1 & 1 & 45.7 \\
\hline Shale & 29.3 & 0.8 & 2.6 & 12.1 & l & 14.7 & 1.0 & l & 39.5 \\
\hline
\end{tabular}

TABLE 4: Clay mineral relative content of the surrounding rock.

\begin{tabular}{|c|c|c|c|c|c|c|c|c|}
\hline \multirow{2}{*}{ Lithology } & \multicolumn{6}{|c|}{ Clay mineral relative content $(\%)$} & \multicolumn{2}{|c|}{$\begin{array}{c}\text { Mixed layer than } \\
(\%)\end{array}$} \\
\hline & S & $\mathrm{I} / \mathrm{S}$ & It & Kao & $\mathrm{C}$ & $\mathrm{C} / \mathrm{S}$ & $\mathrm{I} / \mathrm{S}$ & $\mathrm{C} / \mathrm{S}$ \\
\hline Mudstone & 1 & 58 & 15 & 19 & 8 & I & 40 & I \\
\hline Shale & I & 58 & 12 & 30 & I & I & 50 & I \\
\hline
\end{tabular}

S: smectite; I/S: illite-smectite layer-mixed; It: illite; K: kaolinite; C: chlorite; C/S: chlorite -smectite layer-mixed.

the surrounding rock encounters water and wind, causing significant expansion in the soft rock, which leads to the destruction of the soft rock. This is another cause of the floor heave and roof failure.

SEM (scanning electron microscopy) shows that the shale surface is smoother after magnification of 36 times perpendicular to the bedding direction. After magnification by 27740 times, it is found that the shale surface has curved flaky illite and imonite mixed layer, clay minerals, fine clastic particles, and microholes as shown in Figure 6(a). The paral- lel bedding direction shows the directional distribution of thin-bedded illite and imonite mixed layers, and there are some biofossil fragments and micropores in the shale, which is also one of the reasons for the high oil content of the shale, as shown in Figure 6(b). Extremely well-developed horizontal and vertical cracks penetrate the coal body as shown in Figure 6(c), which is the main reason for the low strength of the coal body. The mudstone has a thin layer with a flocculent structure, as shown in Figure 6(d). Due to its high clay content, the structure of mudstone is relatively loose. 


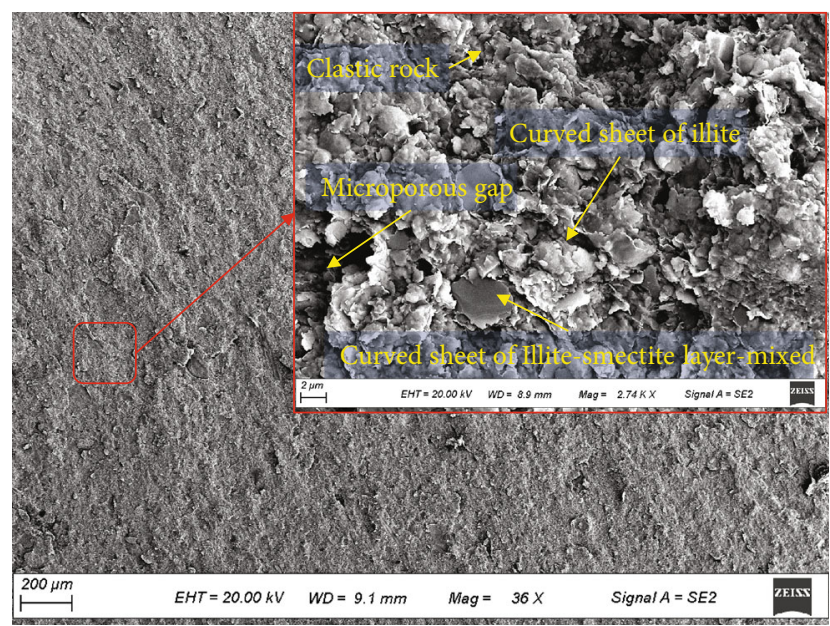

(a)

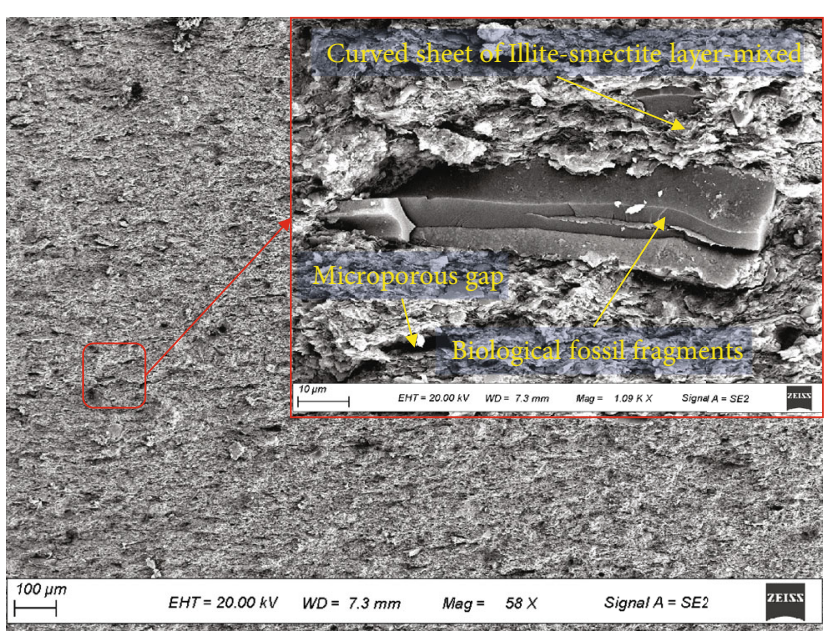

(b)

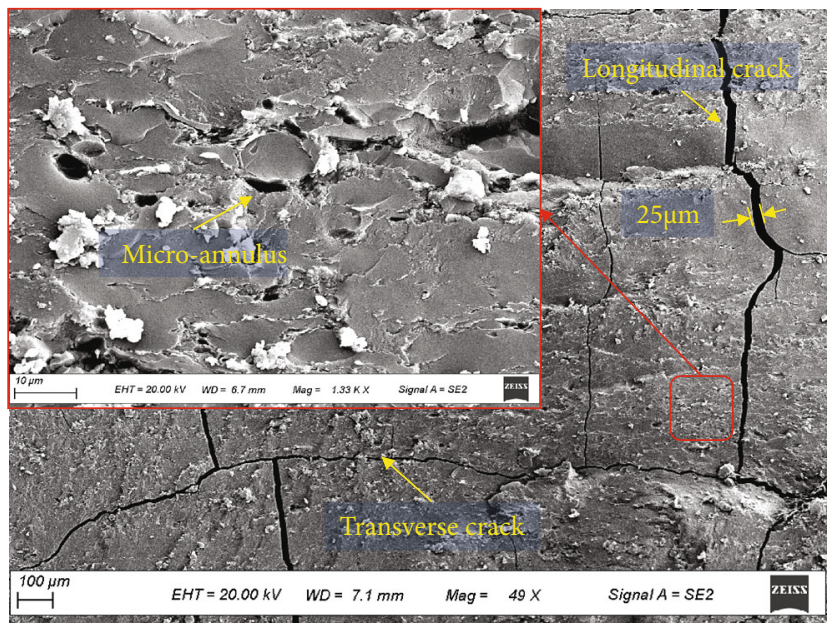

(c)

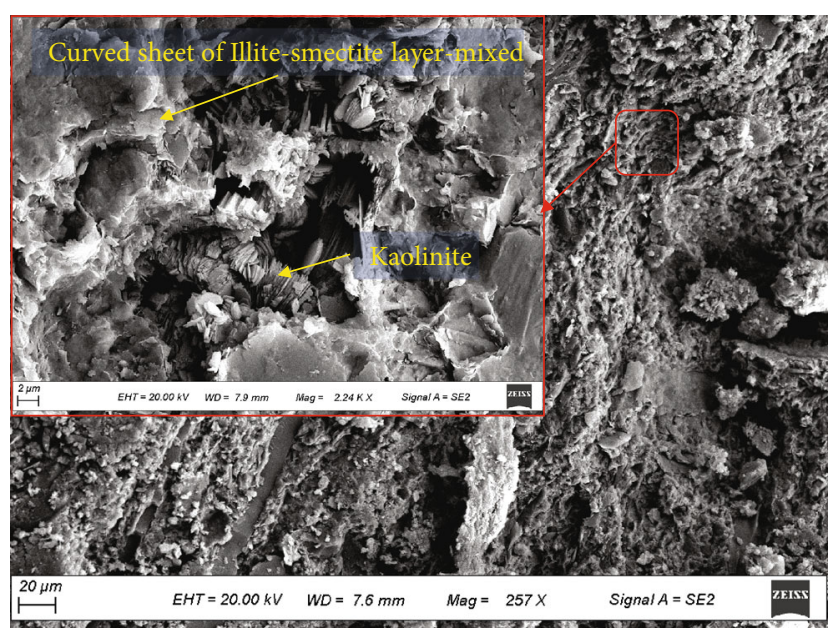

(d)

FIGURE 6: SEM of surrounding rock. (a, b) SEM of mudstone. (c, d) SEM of shale.

3.2.3. Measurement of the Geostress. We conducted on-site measurements of the geostress on the working face. The results show that the S2 mining area is dominated by horizontal tectonic stress, with a maximum value of 22.76 MPa, which is 1.22 times the self-weight stress. The direction of the maximum horizontal principal stress is east-west (EW). The angle between the direction of the roadway and the maximum stress is greater than $70^{\circ}$, which is also one of the reasons for the large deformation of the roadway. 

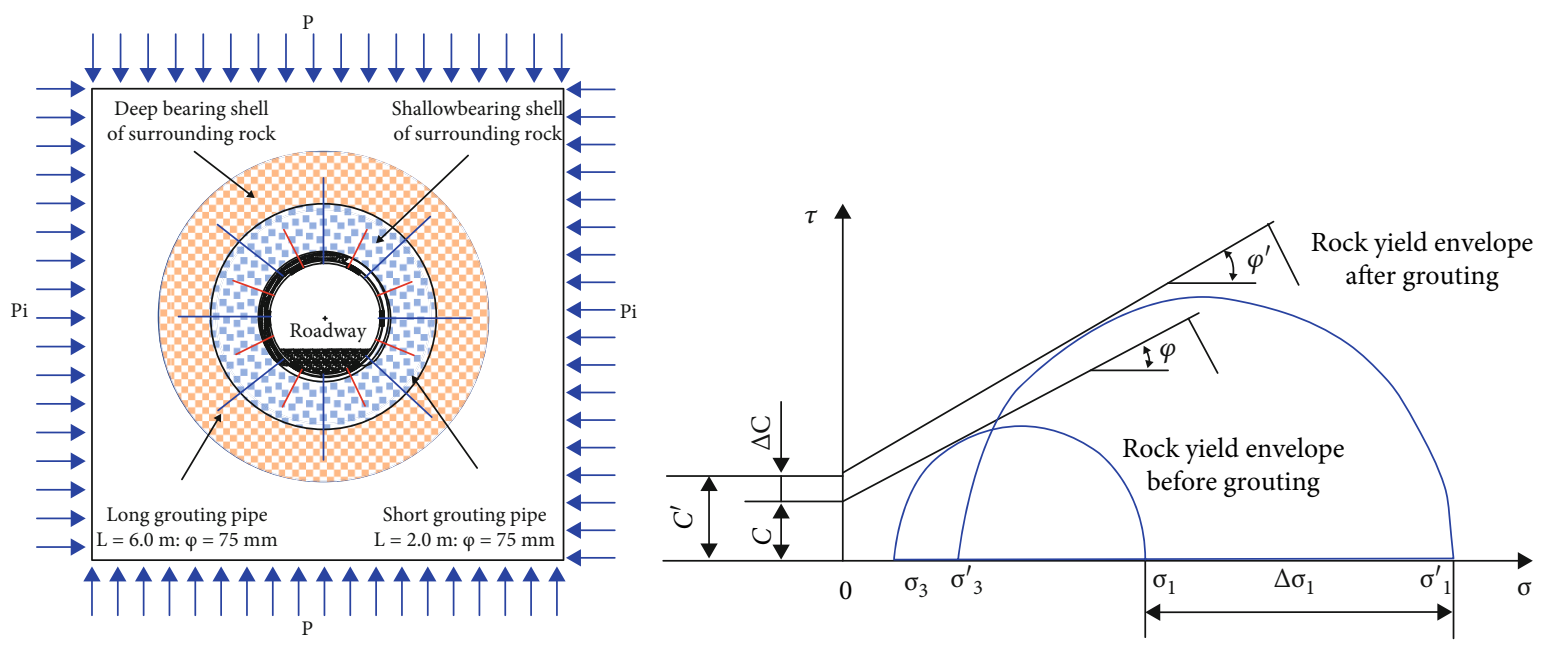

Figure 7: Double-shell grouting reinforcement mechanism.

TABLe 5: Physical and mechanical properties of grouting materials.

\begin{tabular}{|c|c|c|c|c|c|}
\hline 1 & Initial grouting time & 2018.6 .20 & \multicolumn{2}{|c|}{ Water: solid } & $0.52: 1$ \\
\hline & \multicolumn{5}{|c|}{ Cement and admixtures } \\
\hline \multirow{3}{*}{2} & & & xtures $(8 \%)$ & & \\
\hline & Water reducing agent & Bentonite & Accelerator & $\begin{array}{l}\text { Expansive } \\
\text { agent }\end{array}$ & Other \\
\hline & 2.0 & 0.4 & 0.2 & 5.0 & 0.4 \\
\hline
\end{tabular}

Physical and mechanical properties of grouting materials

\begin{tabular}{|c|c|c|c|c|c|c|c|c|}
\hline 3 & $\begin{array}{l}\text { Liquid } \\
\text { viscosity }\end{array}$ & $\begin{array}{l}\text { Liquid } \\
\text { time }\end{array}$ & $\begin{array}{l}\text { Softening plasticity } \\
\text { time }\end{array}$ & $\begin{array}{l}\text { Hardening plastic } \\
\text { time }\end{array}$ & $\begin{array}{l}\text { Final setting } \\
\text { time }\end{array}$ & Inflation rate & $\begin{array}{c}\text { Bulk } \\
\text { density }\end{array}$ & $\begin{array}{l}\text { Compressive } \\
\text { strength }\end{array}$ \\
\hline & $/ \mathrm{s}$ & \multicolumn{4}{|c|}{$/ \mathrm{min}$} & $\%$ & $\mathrm{~g} / \mathrm{cm}^{3}$ & $\mathrm{MPa}$ \\
\hline & 37.26 & 40 & 20 & 20 & 70 & 0.43 & 1.75 & $>30$ \\
\hline
\end{tabular}

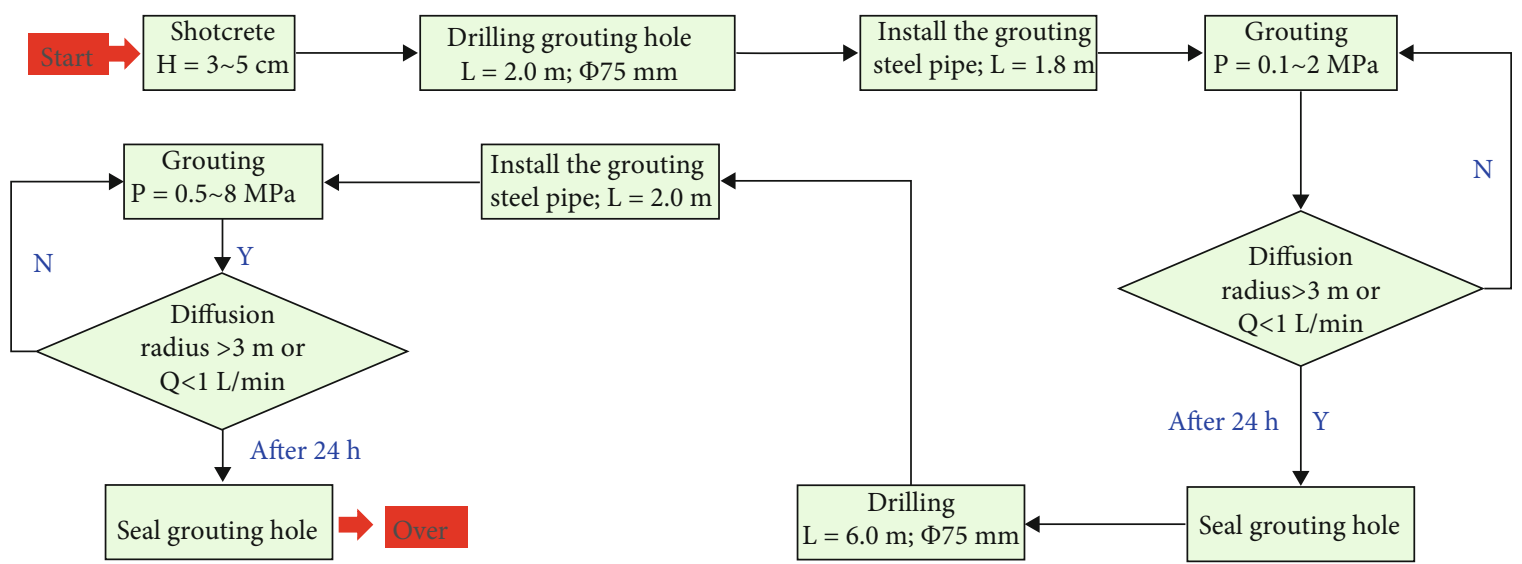

FIGURE 8: Grouting process and control standards.

The analysis above shows that the strength values of the surrounding rock are all lower than $20 \mathrm{MPa}$, which shows that it is a typical soft rock. Although the maximum horizontal principal stress is only $12.05 \mathrm{MPa}$, the strength-tostress ratio is about 3 , and the coal and rock mass are in a state of high in situ stress. However, due to the high content of clay in the roof and bottom and the developmental cracks, which become the main channels to conduct water under certain conditions, the strength of the surrounding rock is greatly reduced after encountering water. In addition, in the original support plan, although the anchor cable of $\varphi 28.6$ was used, the initial pretightening force was only 


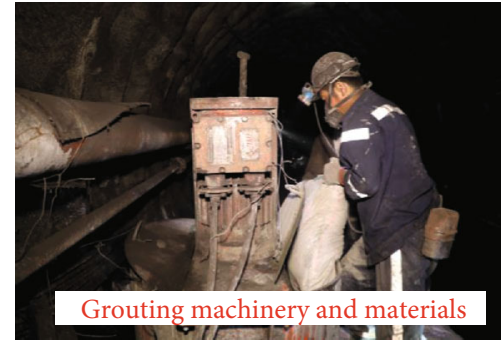

(a)

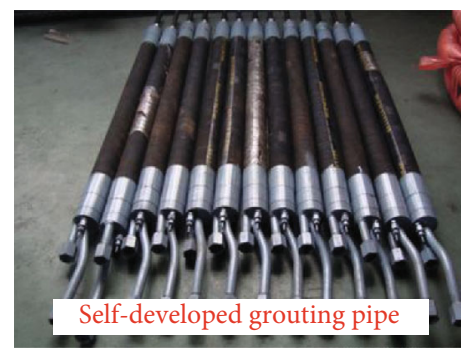

(c)

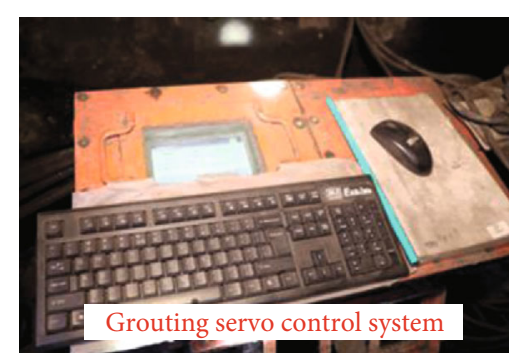

(b)

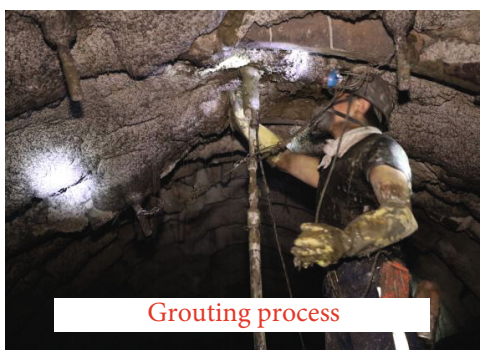

(d)

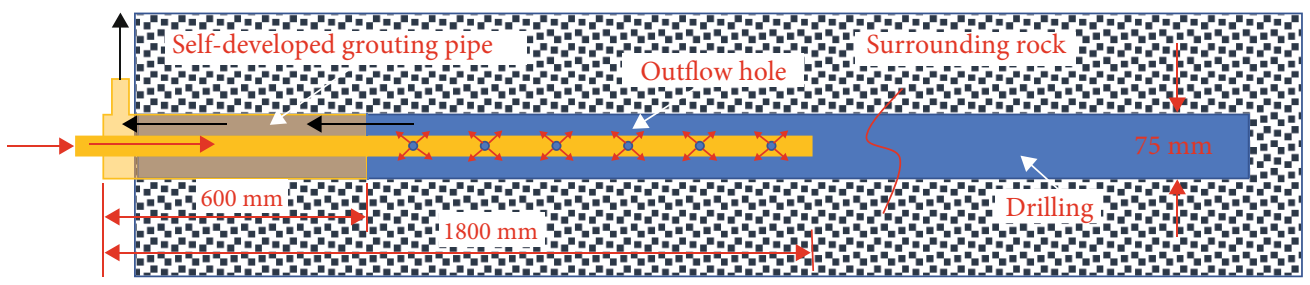

(e)

FIGURE 9: On-site grouting process and a newly developed grouting pipe installation method.

$175 \mathrm{kN}$. The tension test of the anchor cable shows that the pretightening force is only $150 \mathrm{kN}$, but the anchoring force can reach $380 \mathrm{kN}$ after field testing. This shows that the anchor cable with the low pretension cannot mobilize the stress of the deep surrounding rock. The short anchor bolt and the long anchor cable with low pretension cannot form a stress overlap, and their stress-bearing arch strengths are low and not enough to resist the strong mining activity. The U36 circular arch is used as the last line of defense against the deformation of the soft rock roadway. Its rigidity is high, but it cannot be adapted to the rheological characteristics of the soft rock. The rheological properties of the bottom argillaceous siltstone after encountering water and the nonuniformly distributed load under the deviator stress caused by roof engineering leading to obvious asymmetric deformation, finally causing the metal shed to be destroyed first from the bottom heave and then successively form severe shrinkage and deformation, resulting in complete instability.

\section{Double-Shell Grouting Technology}

Grouting and reinforcement of broken coal and rock mass can improve the mechanical properties of the weak structural surface and increase the cohesive force and internal friction angle of the broken coal and rock mass [21]. The cementation effect of the grouting material can increase the internal relative displacement resistance between the discon-

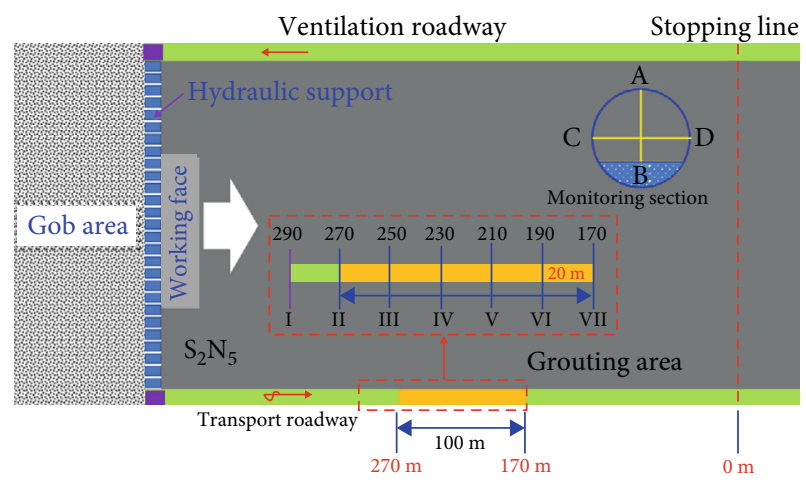

Figure 10: Overview of the testing site.

tinuous blocks of broken coal and rock mass, thereby improving the overall stability and integrity of the surrounding rock [22]. In addition, grouting materials can penetrate the fissures of the surrounding rock to form a skeleton bearing structure, improve the residual strength of the crushed surrounding rock, and give full play to the self-stability of the coal and rock mass [23].

According to the engineering geological conditions of Xiaokang Coal Mine, the concept of double-shell grouting is proposed, namely, shallow low-pressure grouting and deep high-pressure split grouting, as shown in Figure $7(\mathrm{a})$. 


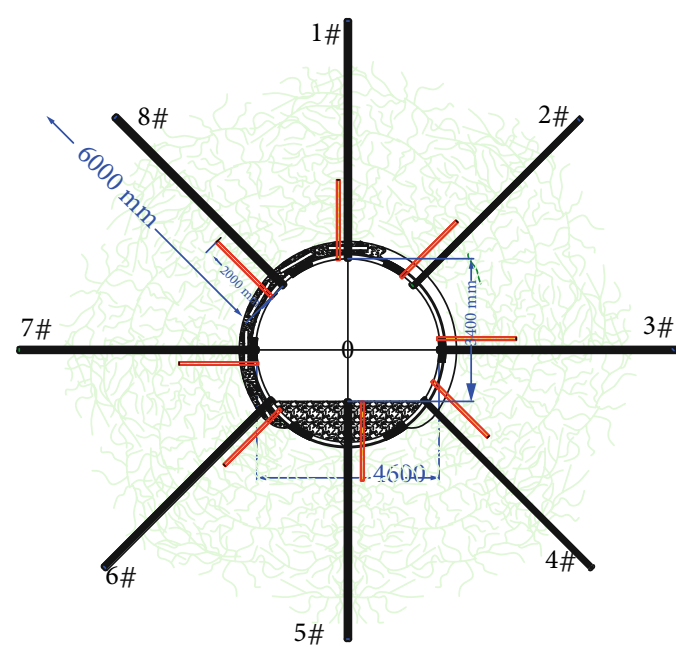

Split grouting pipe
Grouting pipe

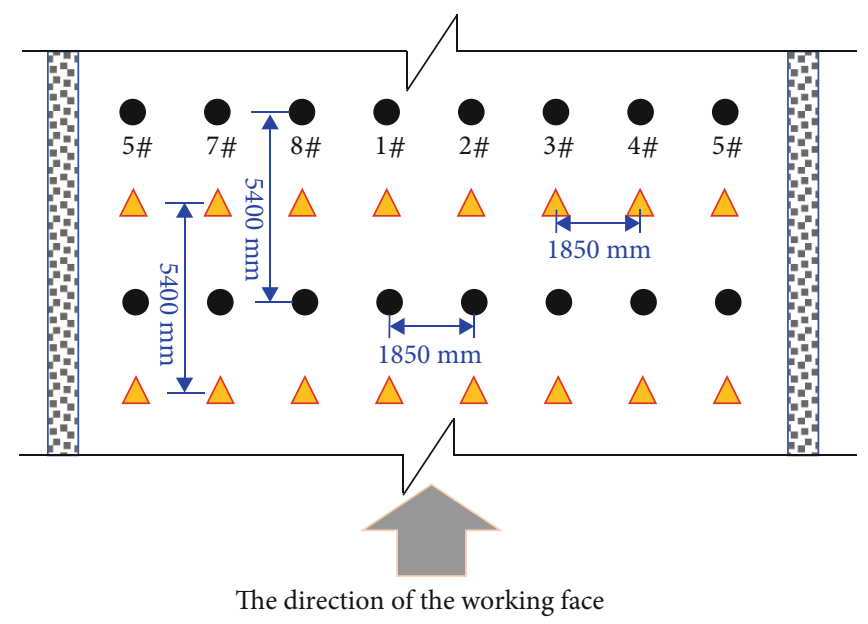

(b)

FIGURE 11: Support design of grouting reinforcement.

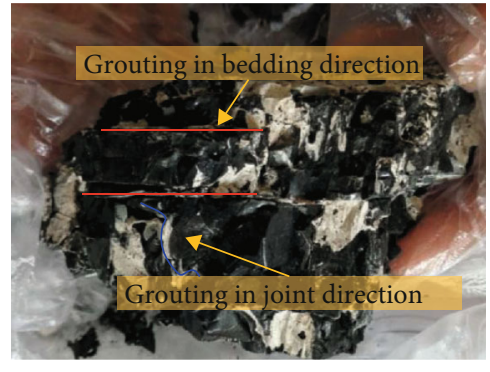

(a)

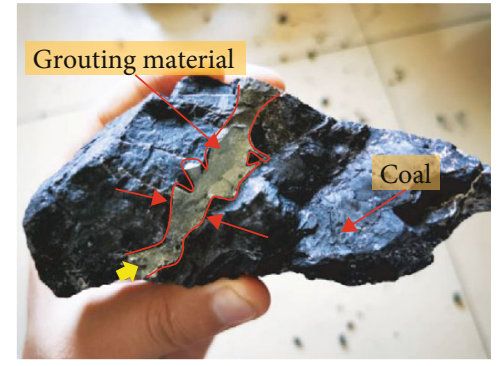

(b)

FIGURE 12: Sample of the grouting block. (a) Sample of the shallow coal. (b) Sample of the deep coal.

In addition, considering that the length of the initial supporting anchor cable is $7.3 \mathrm{~m}$, it is hoped that the internal grouting can be carried out on the surrounding rock within its range without damaging the anchor section of the anchor cable. The grouting is carried out as follows:

(1) A large amount of grouting material is poured into the coal body so that a harder thin plate is formed in the shallow coal body to resist the deformation of the surrounding rock. At the same time, it also provides an isolation layer for the high-pressure fracturing grouting

(2) Compared with the shallow surrounding rock, the deep surrounding rock has fewer fissure channels. High-pressure fracturing grouting technology can inject the grouting material into the surrounding rock along its structural plane to improve the cohesion $(c)$ and friction angle $(\varphi)$ of the coal mass as shown in Figure 7(b). At the same time, a fissure framework is formed inside the coal body to further enhance the coal body's ability to resist deformation
Grouting technology is widely used in surrounding rock reinforcement [24]. Cement materials have the characteristics of low cost and good performance and are commonly used to manage soft rock roadways in coal mines [25]. In the Xiaokang coal mine, the deformation of the soft rock roadway before mining was about $300 \mathrm{~mm}$, which was able to stay steady. In addition, a large number of cracks were detected in the surrounding rock by borehole visitation. Therefore, P.O52.5 concrete was chosen as the grouting material. In order to fill the cracks in the coal and rock mass, an expansion agent which accounts for about $0.4 \%$ of the total composition is specially added. The volume expansion rate of the grouting material is about $0.43 \%$, the final setting time is 70 minutes, and the final strength is not less than $30 \mathrm{MPa}$. The mechanical properties of the grouting materials are shown in Table 5.

4.1. Low-Pressure Grouting Technology. To prevent the grouting material from leaking, the surrounding rock was sprayed with $3 \sim 5 \mathrm{~cm}$ of thick concrete. Then, holes with a diameter of $75 \mathrm{~mm}$ and a depth of $2.0 \mathrm{~m}$ and $8.0 \mathrm{~m}$ were 


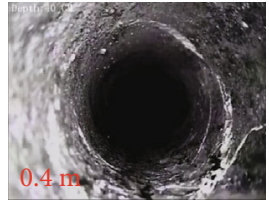

(a) $0.4 \mathrm{~m}$

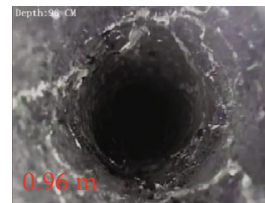

(c) $0.96 \mathrm{~m}$

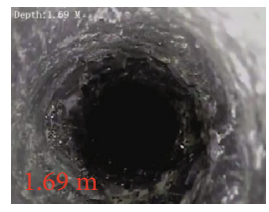

(e) $1.69 \mathrm{~m}$

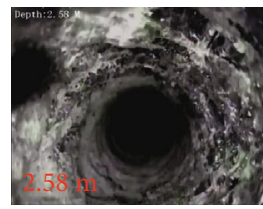

(g) $2.58 \mathrm{~m}$

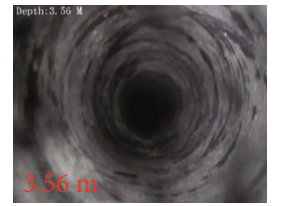

(i) $3.56 \mathrm{~m}$

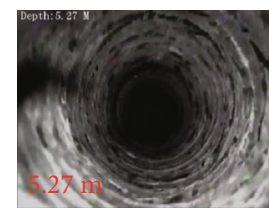

(k) $5.27 \mathrm{~m}$

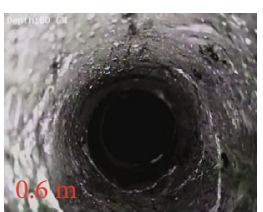

(b) $0.6 \mathrm{~m}$

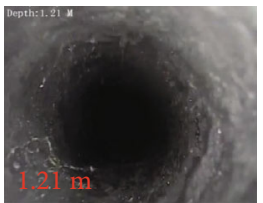

(d) $1.21 \mathrm{~m}$

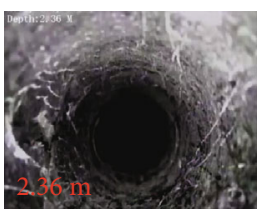

(f) $2.36 \mathrm{~m}$

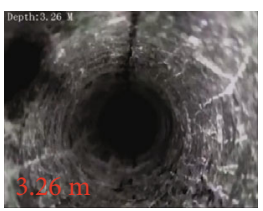

(h) $3.26 \mathrm{~m}$

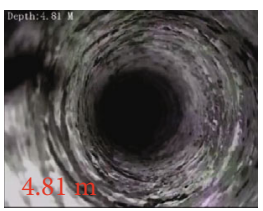

(j) $4.81 \mathrm{~m}$

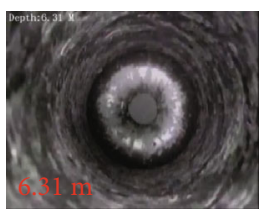

(1) $6.31 \mathrm{~m}$

FIGURE 13: Results of the borehole observations.

drilled in the shallow and deep surrounding rock. The detailed grouting process is shown in Figure 8. The on-site grouting process is shown in Figures 9(a), 9(b), and 9(d). A newly developed grouting pipe with a length of $1.8 \mathrm{~m}$ and an outer diameter of $75 \mathrm{~mm}$ as shown in Figure 9(c) was installed as shown in Figure 9(e).

\subsection{High-Pressure Split Grouting Technology. Split grouting} technology uses high-pressure grouting pumps to split the surrounding rock along the bedding or weak surfaces. By injecting thick slurry into the fissures, the surrounding rock is compacted and the strength of the surrounding rock is increased. The grouting flow rate should be kept at $20 \mathrm{~L} / \mathrm{min}$ as much as possible. If the flow rate is too small, it will cause the slurry to condense in the equipment and pipelines, and the flow rate will be prone to slurry leakage.
Since the grout enters the initial setting state in about 40 minutes, the grouting time of each barrel of grout should not exceed 40 minutes. The detailed grouting process is shown in Figure 8.

\section{Field Test and Evaluation of the Controlling Effect}

5.1. Selection of the Testing Site. The grouting test was carried out on $100 \mathrm{~m}(270 \mathrm{~m} \sim 170 \mathrm{~m})$ of the S2N5 transport roadway. Monitoring points were created at $20 \mathrm{~m}$ intervals and numbered II-VII in sequence. I monitoring point was used for data analysis and comparison as shown in Figure 10. In the grouting test section, the deformation of the roadway between the roof and floor $(\mathrm{AB})$ and that of the two sides of the roadway were measured (CD). 


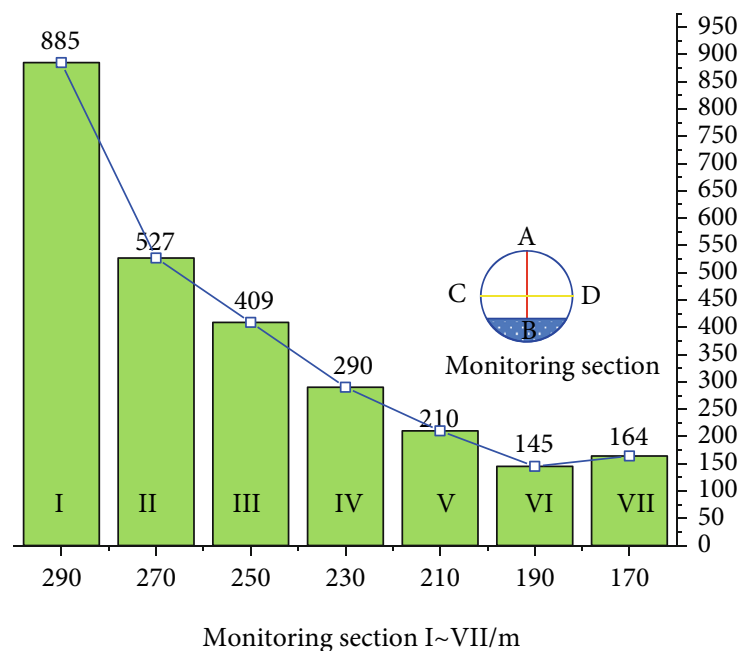

$\mathrm{AB}$

$-\square \mathrm{AB}$

(a)

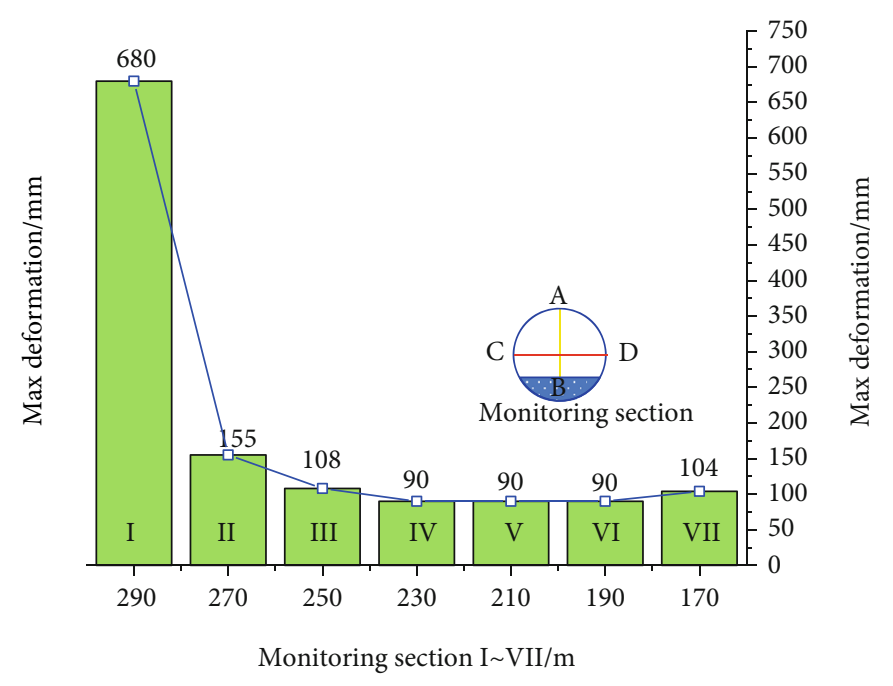

(b)

FIGURE 14: Statistics of the maximum deformation of the test section. (a) Displacement between the roof and floor. (b) Displacement of the two sides of the roadway.

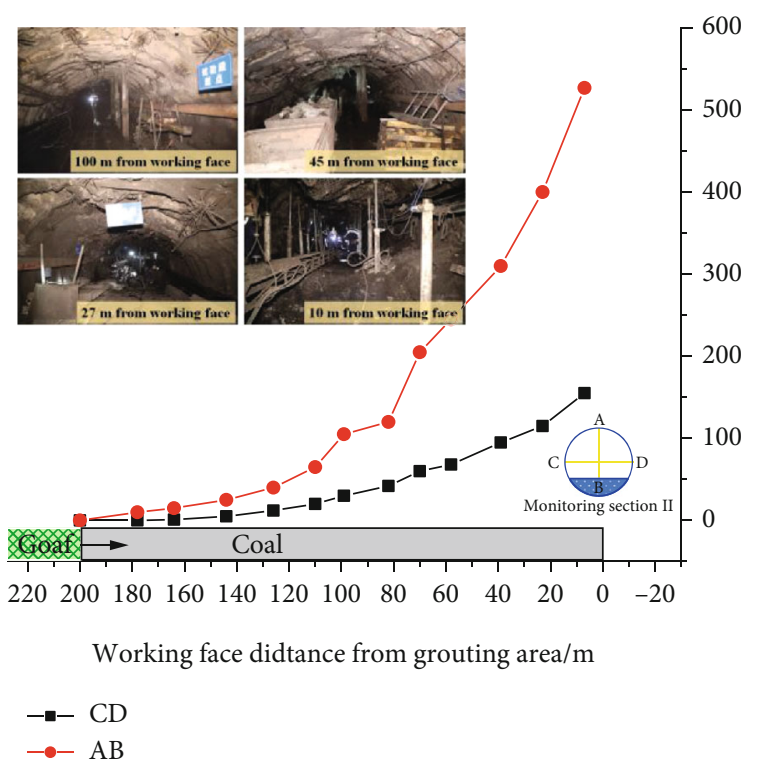

(a)

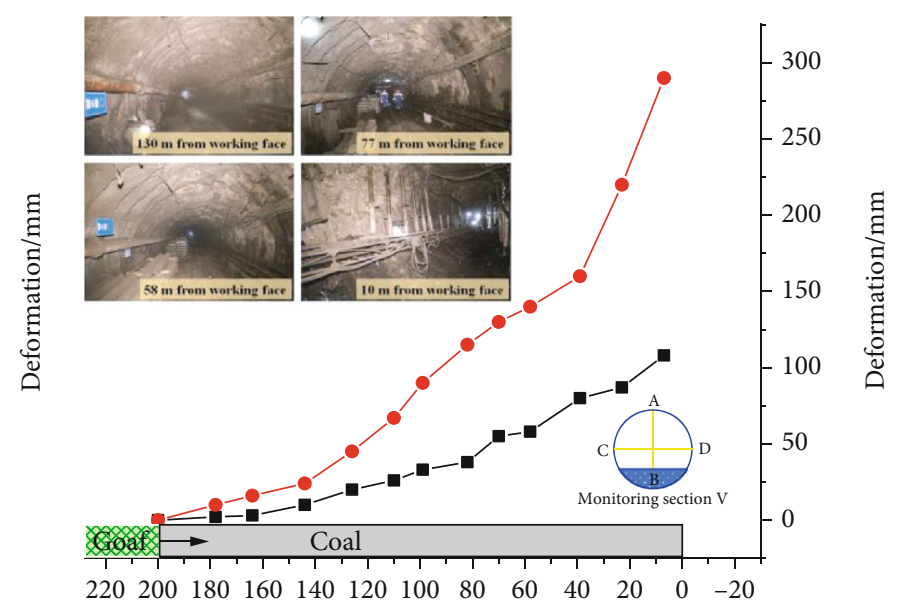

Working face didtance from grouting area/m

$-1-\mathrm{CD}$

$-\bullet \mathrm{AB}$

FIgURE 15: Statistics of the maximum deformation of the test section. (a) Displacement between the roof and floor. (b) Displacement of the two sides of the roadway.

5.2. Grouting Reinforcement Support Design. Considering the original roadway support form in the Xiaokang coal mine, a double-shell grouting reinforcement scheme is proposed as shown in Figure 11(a). The alternate arrangement of the shallow and deep drilling holes is shown in Figure 11(b).

\subsection{Evaluation of Grouting}

5.3.1. Grouting Block Analysis. To evaluate the effect of grouting, rock samples were evaluated. The shallow coal seam was relatively broken, and the grouting material could penetrate the bedding and joints of the coal under the action of lower pressure as shown in Figure 12(a). The grouting material had a high bonding force to the fracture surface, which improved the deformation rigidity of the fractured coal and rock mass structure so that the integrity of the coal mass was improved. The deep coal seam was relatively complete, and the grouting material could expand the microcracks in the coal under the action of high-pressure splitting. Through the 
squeezing action, the $c$ and $\varphi$ of the coal body were enhanced as shown in Figure 12(b).

5.3.2. Borehole Observations. An electronic borehole observation instrument, which is an effective method for grouting evaluation, was used to observe the grouting borehole [26-29]. Observations showed that the shallow surrounding rock fissures were relatively developed and that the grouting material could fully fill the coal seam fissures to improve the integrity of the coal seam as shown in Figures 13(a)-13(e). Although there were fewer fissures in the deep surrounding rock, the internal structural surface of the coal seam was still filled under the action of the high-pressure fracturing grouting as shown in Figures 13(f)-13(1).

5.3.3. Deformation Curve of the Surrounding Rock. The statistics of the maximum deformation of the surrounding rock in the grouting test area are shown in Figure 14, and the maximum displacement between the roof and floor is shown in Figure 14(a). After grouting, the displacement between the roof and floor decreased from a maximum of $885 \mathrm{~mm}$ to $145 \mathrm{~mm}$, which is a decrease of $83.5 \%$. The deformation of the two sides of the roadway decreased from a maximum of $680 \mathrm{~mm}$ to $90 \mathrm{~mm}$, which is a decrease of $86.8 \%$, as shown in Figure 14(b). Sections II and V were selected for detailed analysis, as shown in Figures 15(a) and 15(b). The results show that the deformation of the mining roadway is obviously reduced and normal production can be maintained after grouting. The influence of the advanced abutment pressure was reduced to about $150 \mathrm{~m}$. The roadway deformation was still dominated by roof subsidence, but the deformation was significantly reduced.

\section{Conclusion}

(1) The S2N5 working face is a typical three-soft coal seam, which shows obvious rheological characteristics under the action of high geostress. The original support structure could not control the deformation of the surrounding rock, resulting in the failure of supporting structures

(2) The pretension of the bolts and anchor cables was too low to consolidate the broken surrounding rock and form a stress-bearing structure. The superposition of the advanced abutment pressure and the geostress is the dynamic source of the large deformation in the S2N5 working face

(3) Grouting reinforcement can effectively improve the value of cohesion $(c)$, friction angle $(\varphi)$, and strength of the broken surrounding rock $\left(\sigma_{1}\right.$ and $\left.\sigma_{3}\right)$. The surrounding rock bonded by grouting materials and bolts and anchor cables forms a stress-bearing structure that prevents large deformation from occurring in the roadway

(4) Double-shell grouting technology can effectively improve the overall mechanical properties of the surrounding coal and rock mass and prevent the large deformation and failure of the roadway using a newly developed grouting pipe made in this study

\section{Data Availability}

All the data, models, or codes that support the findings of this study are available from the corresponding author upon reasonable request.

\section{Conflicts of Interest}

The authors declare that they have no conflicts of interest.

\section{Acknowledgments}

The authors gratefully acknowledge the funding provided by the National Natural Science Foundation of China (41941018).

\section{References}

[1] M. C. He, H. P. Xie, S. P. Peng, and Y. D. Jiang, "Study on rock mechanics in deep mining engineering," Chinese Journal of Rock Mechanics and Engineering, vol. 24, no. 16, pp. 28032813, 2005.

[2] M. C. He, Q. Wang, and Q. Y. Wu, "Innovation and future of mining rock mechanics," Journal of Rock Mechanics and Geotechnical Engineering, vol. 13, no. 1, pp. 1-21, 2021.

[3] S. Xie, E. Li, S. Li, J. Wang, C. He, and Y. Yang, "Surrounding rock control mechanism of deep coal roadways and its application," International Journal of Mining Science and Technology, vol. 25, no. 3, pp. 429-434, 2015.

[4] Q. Wang, M. C. He, S. C. Li et al., "Comparative study of model tests on automatically formed roadway and gob-side entry driving in deep coal mines," International Journal of Mining Science and Technology, vol. 31, no. 4, pp. 591-601, 2021.

[5] H. P. Kang and Z. Q. Feng, "Status and development tendency of roadway grunting reinforcement technology in coal mine," Coal Mining Technology, vol. 18, no. 3, pp. 1-7, 2013.

[6] F. N. Wang, Z. B. Guo, X. B. Qiao et al., "Large deformation mechanism of thin-layered carbonaceous slate and energy coupling support technology of NPR anchor cable in Minxian Tunnel: A case study," Tunnelling and Underground Space Technology, vol. 117, p. 104151, 2021.

[7] N. Yang, W. T. Li, C. Xuan, and Y. H. Zhang, "Solid support system construction technology of U- type concrete filled steel tube arch of soft rock roadway in kilometer deep mine," Journal of China Coal Society, vol. 47, no. 12, pp. 82-86, 2016.

[8] Z. F. Zhang, H. P. Kang, Z. Y. Jiang et al., "Study and application of high-pressure splitting grouting modification technology in coalmine with depth more than $1000 \mathrm{~m}$," Journal of China Coal Society, vol. 45, no. 3, pp. 972-981, 2020.

[9] G. Li, M. He, G. Zhang, and Z. Tao, "Deformation mechanism and excavation process of large span intersection within deep soft rock roadway," Mining Science and Technology (China), vol. 20, no. 1, pp. 28-34, 2010.

[10] G. C. Li, Z. H. Jiang, C. X. Lv, C. Huang, G. Chen, and M. Li, "Instability mechanism and control technology of soft rock roadway affected by mining and high confined water," International Journal of Mining Science and Technology, vol. 25, no. 4, pp. 573-580, 2015.

[11] W. Fangtian, Z. Cun, W. Shuaifeng, Z. Xiaogang, and G. Shenghua, "Whole section anchor-grouting reinforcement technology and its application in underground roadways with 
loose and fractured surrounding rock," Tunnelling and Underground Space Technology, vol. 51, pp. 133-143, 2016.

[12] Q. Wang, R. Pan, B. Jiang et al., "Study on failure mechanism of roadway with soft rock in deep coal mine and confined concrete support system," Engineering Failure Analysis, vol. 81, pp. 155-177, 2017.

[13] S. Chen, A. Wu, Y. Wang, X. Chen, R. Yan, and H. Ma, “Study on repair control technology of soft surrounding rock roadway and its application," Engineering Failure Analysis, vol. 92, pp. 443-455, 2018.

[14] W. Zhang, X. Zhu, S. Xu, Z. Wang, and W. Li, "Experimental study on properties of a new type of grouting material for the reinforcement of fractured seam floor," Journal of Materials Research and Technology, vol. 8, no. 6, pp. 5271-5282, 2019.

[15] C. Yang, J. Guo, J. Lian, and Z. Wang, "Study on microscopic roadbed grouting mechanism based on CFD-DEM coupling algorithm," Mathematical Problems in Engineering, vol. 2020, 9 pages, 2020.

[16] Z. C. Wang, J. Tang, W. Li, X. G. Zhu, and D. S. Zhao, "Combined support technology of bolting net and $U$ section steel support in soft rock roadway," Safety of Coal Mine, vol. 45, no. 12, pp. 156-159, 2014.

[17] J. Shen and Y. Zhang, "Theory and application of gob-side entry retaining in thick three-soft coal seam," Geofluids, vol. 2021, Article ID 6157174, 16 pages, 2021.

[18] C. Zhu, K. Zhang, H. Cai et al., "Combined application of optical fibers and CRLD bolts to monitor deformation of a pitin-pit foundation," Advances in Civil Engineering, vol. 2019, Article ID 2572034, 16 pages, 2019.

[19] T. Zhigang, Z. Chun, W. Yong, W. Jiamin, H. Manchao, and Z. Bo, "Research on stability of an open-pit mine dump with fiber optic monitoring," Geofluids, vol. 2018, Article ID 9631706, 20 pages, 2018.

[20] D. D. Zhang, C. Y. Ma, Y. Y. Duan, W. G. Du, J. X. Liu, and J. Chai, "Wavelength characteristic analysis of a FBG array embedded in quaternary unconsolidated strata during a deep borehole installation," Journal of Sensors, vol. 2021, Article ID 1207374, 13 pages, 2021.

[21] C. J. Deng, F. N. Dang, X. Z. Chen, Z. Miao, and L. L. Chen, "Experimental study on grouting effect and mechanical properties of the rockfill materials grouted with SCM," Advances in Civil Engineering, vol. 2020, Article ID 8834686, 9 pages, 2020.

[22] J. Wu, B. Chen, S. Chai, and W. Kong, "Experimental study on compression characteristics of gangue grouting filling materials," Geotechnical and Geological Engineering, vol. 38, no. 5, pp. 4557-4565, 2020.

[23] X. Wang, Q. Qin, and Z. Xiong, "Comprehensive evaluation for grouting effect of fractured surrounding rock in deep roadway," Chinese Journal of Underground Space and Engineering, vol. 15, no. 2, p. 576, 2019.

[24] H. Wu, D. Ma, A. J. S. Spearing, and G. Y. Zhao, "Fracture phenomena and mechanisms of brittle rock with different numbers of openings under uniaxial loading," Geomechanics and Engineering, vol. 25, no. 6, pp. 481-493, 2021.

[25] Y. Wang, B. Zhang, B. Li, and C. H. Li, “A strain-based fatigue damage model for naturally fractured marble subjected to freeze-thaw and uniaxial cyclic loads," International Journal of Damage Mechanics, vol. 30, no. 9, pp. 1305-1323, 2021.
[26] Q. Wang, Z. Jiang, B. Jiang, H. Gao, Y. Huang, and P. Zhang, "Research on an automatic roadway formation method in deep mining areas by roof cutting with high-strength boltgrouting," International Journal of Rock Mechanics and Mining Sciences, vol. 128, p. 104264, 2020.

[27] X. S. Li, K. Peng, J. Peng, and H. Xu, "Effect of cyclic wettingdrying treatment on strength and failure behavior of two quartz-rich sandstones under direct shear," Rock Mechanics and Rock Engineering, pp. 1-8, 2021.

[28] F. N. Wang, S. S. Yin, A. P. Guo et al., "Frame structure and engineering applications of the multisource system cloud service platform of monitoring of the soft rock tunnel," Geofluids, vol. 2021, Article ID 6672732, 15 pages, 2021.

[29] F. Wu, H. Zhang, Q. L. Zou, C. B. Li, J. Chen, and R. B. Gao, "Viscoelastic-plastic damage creep model for salt rock based on fractional derivative theory," Mechanics of Materials, vol. 150, p. 103600, 2020. 